\title{
Region-specific expression of nitric oxide synthases in the bovine oviduct during the oestrous cycle and in vitro
}

\author{
S E Ulbrich, S Rehfeld ${ }^{2}$, S Bauersachs ${ }^{2}$, E Wolf ${ }^{2}$, R Rottmayer ${ }^{2}$, \\ S Hiendleder ${ }^{2}, M_{\text {Vermehren }}{ }^{3}$, F Sinowatz ${ }^{3}$, H H D Meyer \\ and $\mathbf{R}$ Einspanier ${ }^{\mathbf{1}}$
}

Physiology-Weihenstephan, Technical University of Munich, Alles Hörsaalgebäude, 85350 Freising, Germany

${ }^{1}$ Institute of Veterinary Biochemistry, Free University of Berlin, Oertzenweg 19b, D-14163 Berlin, Germany

${ }^{2}$ Institute of Molecular Animal Breeding and Biotechnology, Gene Centre of the Ludwig-Maximilians-University Munich, Munich, Germany

${ }^{3}$ Institute of Veterinary Anatomy, Histology and Embryology, Ludwig-Maximilians-University Munich, Veterinaerstr. 13, 80539 Munich, Germany

(Requests for offprints should be addressed to R Einspanier; Email: einspani@zedat.fu-berlin.de)

\begin{abstract}
Nitric oxide synthases (NOS) account for the endogenous production of nitric oxide (NO), a small and permeable bioreactive molecule. $\mathrm{NO}$ is known to act as a paracrine mediator during various processes associated with female reproduction. In the present study, the mRNA expression of the endothelial (eNOS) and inducible (iNOS) NO synthases were examined in bovine oviduct epithelial cells (BOEC) during the oestrous cycle. In addition, eNOS and iNOS mRNA and protein were localised by in situ hybridisation and immunocytochemistry respectively. Furthermore, the effects of exogenously applied oestradiol-17 $\beta$ and progesterone on NOS mRNA regulation were studied in a suspension culture of BOEC. The eNOS mRNA abundance was low around ovulation (day 0$)$ and increased significantly until pro-oestrus (day 18 ) in the ampulla. Immunoreactive protein of eNOS was
\end{abstract}

detected predominantly in endothelial cells as well as in secretory oviduct epithelial cells at pro-oestrus. The iNOS mRNA concentration was significantly reduced in the isthmus at pro-oestrus (day 18) and oestrus (day 0) compared with persistently high levels in the ampulla. By in situ hybridisation, specific iNOS transcripts were additionally demonstrated in the oviduct epithelium. Immunoreactive iNOS protein was localised in secretory epithelial cells as well as in the lamina muscularis. The in vitro stimulation showed that both NOS were stimulated by progesterone, but not by oestradiol- $17 \beta$. The region-specific modulated expression of eNOS and iNOS provides evidence for an involvement of endogenously produced NO in the regulation of oviductal functions. Journal of Endocrinology (2006) 188, 205-213

\section{Introduction}

The oviduct is responsible for the accommodation of the gametes and the early embryo by providing an optimal environment for successful fertilisation. In addition, it accounts for the transport of the gametes and the embryo into the uterus. The anorganic free radical nitric oxide $(\mathrm{NO})$ is a small, unstable and permeable molecule that can pass through membranes by diffusion. NO is an important intercellular regulatory molecule and a major paracrine mediator, functioning as a vascular, immunological and neuronal signalling molecule (Ignarro et al. 2001). NO can react with several targets by exerting unspecific immune responses (Guzik et al. 2003). By binding to guanylyl cyclase, cyclic guanosine monophosphate (cGMP)-specific proteinases (protein kinase $\mathrm{G}$ ), $\mathrm{Na}^{+}$ions and phosphodiesterases can be activated, leading to modulated gene expression (Nathan \& Xie 1994). The effect of NO on vasodilatation has been demonstrated (Furchgott \& Vanhoutte 1989). NO is assumed to have a broad range of functions in reproductive processes such as oocyte maturation, ovulation, implantation, pregnancy maintenance, labour and delivery (Shukovski \& Tsafriri 1994, JablonkaShariff et al. 1999, Sengoku et al. 2001, Maul et al. 2003).

$\mathrm{NO}$ is produced by the conversion of $\mathrm{L}$-arginine to L-citrulline by the enzyme NO synthase (NOS) with several co-factors in a number of different tissues and cell types. To date, three isoforms of NOS, products of separate genes with different molecular weight but apparently similar molecular structure, have been described: neuronal NOS (nNOS) in the brain and peripheral nervous system; endothelial NOS (eNOS) as a constitutive NOS mainly in the endothelium; and inducible NOS (iNOS), synthesised primarily by activated macrophages, hepatocytes and neutrophils in several tissue types and organs and upon inflammatory stimulation (Moncada et al. 1997). 
Recently, NOS have been identified in the human, bovine and rat oviduct (Bryant et al. 1995, Rosselli et al. 1996, Ekerhovd et al. 1997). Nevertheless, more comprehensive analyses could help to bridge lack of congruency for different species (Chatterjee et al. 1996, Gawronska et al. 2000) with respect to cellular localisation, regions of the oviduct and cycle-dependent regulation. Therefore, the present study investigated thoroughly the expression and localisation of iNOS and eNOS in the bovine oviduct of days $0,3 \cdot 5,12$ and 18 of the oestrous cycle. In addition, the in vivo data were compared with NOS expression in bovine oviduct epithelial cells (BOEC) in vitro. The obtained data can help to assign a specific regulatory role to NOS in the oviduct.

\section{Materials and Methods}

Synchronisation of the oestrous cycle and collection of oviduct samples

Twelve cyclic Simmental heifers 18-24 months old were cycle synchronised by injecting intramuscularly a single dose of $500 \mu \mathrm{g}$ cloprostenol (Estrumate; Essex Tierarznei, Munich, Germany) at dioestrus. Animals were intensively observed for sexual behaviour (i.e. toleration, sweating, vaginal mucus) to determine standing heat, which occurred around $60 \mathrm{~h}$ after Estrumate injection.

Ovary function was monitored by ultrasonographic examination to locate the time frame of ovulation, and blood samples were taken to determine serum progesterone (P4) levels, which were executed in 6-h rhythms. Three animals were slaughtered the morning after standing heat occurred (day 0 ) and three animals each at days $3 \cdot 5,12$ and 18 after oestrus respectively. Final blood samples were taken just before slaughter to determine serum P4 levels. Animals slaughtered at oestrus (day 0) displayed low serum P4 levels $(<1 \cdot 0 \mathrm{ng} / \mathrm{ml})$ and animals slaughtered at dioestrus (day 12) had high serum P4 levels ( $>6 \mathrm{ng} / \mathrm{ml}$ ). Oviducts were trimmed free of surrounding tissue, subdivided into ampulla and isthmus, and dissected in 1-cm-long sections. To isolate the epithelial cells, the sections were stripped with two tweezers, and the epithelia were transferred directly in cryotubes. These tubes were dropped immediately into dry ice, transported in liquid nitrogen and stored at $-80{ }^{\circ} \mathrm{C}$ until further processing. All samples were taken and frozen within $20 \mathrm{~min}$ after death.

\section{In vitro cell suspension culture}

Four heifers were slaughtered on day $3 \cdot 5$ of the oestrous cycle, and BOEC were obtained as described previously (Rottmayer et al. 2005). Briefly, the oviducts were squeezed along the ampulla with forceps. The cell sheets were separated mechanically by repeated passages through syringes and pipetting, and recovered by sedimentation. Cells were cultured in 24-well plates with $800 \mu \mathrm{l}$ TCM-199 supplemented with $2 \%$ serum obtained from heifers on day 3.5 of the oestrous cycle and $0.25 \mathrm{mg} / \mathrm{ml}$ gentamicin at a density of $10^{6}$ cells per well at $38{ }^{\circ} \mathrm{C}$ in a humidified atmosphere of $5 \% \mathrm{CO}_{2}$ in air. BOEC were stimulated with oestradiol-17 $\beta(10 \mathrm{pg} / \mathrm{ml})$ or progesterone $(10 \mathrm{ng} / \mathrm{ml}$ ) (both purchased from Sigma) for 6 and $12 \mathrm{~h}$ respectively. Both experiments were carried out with appropriate negative controls diluting the carrier of the steroid (ethanol and water respectively) in the same way as the steroid itself. Two animals were also used for a short-time stimulation of $2 \mathrm{~h}$. Cells were collected by centrifugation, washed in buffer solution, snap-frozen in liquid nitrogen and stored at $-80{ }^{\circ} \mathrm{C}$ until further investigation.

\section{Reverse transcription and real-time $R T-P C R$}

Total RNA from BOEC in vivo and in vitro was isolated with TRIzol reagent (Invitrogen) according to the manufacturer's instructions. Two-step quantitative real-time RT-PCR with the LightCycler DNA Master SYBR Green I protocol (Roche) was done as described previously (Ulbrich et al. 2004). Briefly, $1 \mu \mathrm{g}$ of each sample of RNA was reverse transcribed in a total volume of $60 \mu \mathrm{l}$ : 5X Buffer (Promega), $10 \mathrm{mM}$ dNTPs (Roche), $50 \mu \mathrm{M}$ hexameres (Gibco BRL), 200 U Superscript RT enzyme (Promega). The conventional PCR was performed in a thermal cycler (Biometra, Göttingen, Germany) as previously described (Berisha et al. 2002). A 7- $\mu$ l volume of each reaction was subsequently subjected to agarose gel electrophoresis followed by ethidium bromide staining. For each of the following real-time PCR reactions, $1 \mu \mathrm{l}$ cDNA was used to amplify specific target genes. In each $\mathrm{PCR}$ reaction, $17 \mathrm{ng} / \mu \mathrm{l} \mathrm{cDNA}$ were introduced and amplified in a $10 \mu \mathrm{l}$ reaction mixture $\left(3 \mathrm{mM} \mathrm{MgCl}_{2}\right.$, $0 \cdot 4 \mu \mathrm{M}$ primer forward and reverse each, 1 Light Cycler DNA Master SYBR Green I; Roche) and compared with a standard curve based on a specific PCR product. Primers were adapted to amplify specific PCR products for $18 \mathrm{~S}$ rRNA (forward: 5'-AAGTCTTTGGGTTCCGGG-3'; reverse: $5^{\prime}$-GGACATCTAAGGGCATCACA-3' [365 bp]), eNOS (forward: 5'-AGGAGTGGAAGTGGTTCCG-3'; reverse: 5'-GCCCCGGTACTACTCTGTCA-3' [126 bp]) and iNOS (forward: $5^{\prime}$-ACCTACCAGCTGACGGGA GAT-3'; reverse: 5'-TGGCAGGGTCCCCTGTGATG-3' [316 bp]). The predicted size of each PCR product is assigned in brackets. The amplified PCR fragments were sequenced once (MWG, Ebersberg, Germany) to verify the resulting PCR product (Einspanier et al. 2002). Thereafter, the specific melting point (MP) of the amplified products served as verification of the product identity $\left(18 \mathrm{~S}\left(\mathrm{MP} 88^{\circ} \mathrm{C}\right.\right.$, fluorescence acquisition at $80^{\circ} \mathrm{C}$ ), eNOS (MP $93{ }^{\circ} \mathrm{C}$, fluorescence acquisition at $87^{\circ} \mathrm{C}$ ) and iNOS (MP $90{ }^{\circ} \mathrm{C}$, fluorescence acquisition at $86{ }^{\circ} \mathrm{C}$ ) 
(Ulbrich et al. 2004). The annealing temperature was $60{ }^{\circ} \mathrm{C}$ for $18 \mathrm{~S}, 61^{\circ} \mathrm{C}$ for iNOS and $66^{\circ} \mathrm{C}$ for eNOS. As negative control, water instead of cDNA was used. The nucleotide sequence for the partial bovine iNOS cDNA was subsequently submitted to the EMBL database (accession no. AJ699400). The cycle number (CP) required to achieve a definite SYBR Green fluorescence signal was calculated by the second derivative maximum method (LightCycler software, Version 3.5.28). The CP was correlated inversely with the logarithm of the initial template concentration.

\section{Data analysis of real-time $R T-P C R$}

The CP determined for the target genes were normalised against the housekeeping gene $18 \mathrm{~S}$. Resulting data are presented as means of CP $(n=3) \pm$ S.E.M. For statistical analysis, the SAS program package release 9.1.3 (2002, SAS Institute, Cary, NC, USA) was used. All data were analysed by one-way ANOVA (analysis of variance). In case of significant different groups, a multiple $t$-test analysis was done with the Bonferroni correction. Results were considered statistically significant at $P<0 \cdot 05$.

\section{In situ hybridisation}

The detailed in situ hybridisation procedure has been described previously (Bauersachs et al. 2005). Briefly, formalin-fixed, paraffin wax-embedded samples were used. Sections were deparaffinised with xylene and immersed in isopropanol. Dried sections were submerged in 2 saline sodium citrate buffer and preheated at $80{ }^{\circ} \mathrm{C}$. Slides were then washed in distilled water and TBS and permeabilised with $0 \cdot 05 \%$ proteinase K (VWR, Ismaning, Germany) in Tris-buffered saline (TBS) at room temperature. Sections were relocated in TBS followed by distilled water and post-fixed for $10 \mathrm{~min}$ in 4\% paraformaldehyde/ PBS. After washing in PBS and distilled water, slides were dehydrated and air-dried. Hybridisation was carried out by overlaying the dried sections with the corresponding biotinylated oligonucleotide probe $(100 \mathrm{pmol} / \mu \mathrm{l})$, diluted 1:20 in in situ hybridisation solution (DAKO, Munich, Germany), and incubating them in a humidified chamber at $38^{\circ} \mathrm{C}$ overnight. The sequence of the iNOS antisense oligonucleotides was $5^{\prime}$-TCCAGCATCTCCTCCCAG TA-3'. RNase-free hybridisation solution (DAKO, Munich, Germany) contained 60\% formamide, $5 \times$ SSC, hybridisation accelerator, RNase inhibitor and blocking reagents. Subsequently, slides were washed in $2 \times$ SSC (2 h $15 \mathrm{~min}$, preheated to $\left.38^{\circ} \mathrm{C}\right)$, distilled water $(25 \mathrm{~min})$ and TBS $(25 \mathrm{~min})$. Hybridised probes were detected with HRP-labelled ABC kit reagents developed by DAB (DAKO, Munich, Germany) according to the manufacturer's instructions. Negative controls were done by exchanging the oligonucleotide probe with the corresponding sense oligonucleotide.

\section{Immunohistochemistry}

For the immunohistochemical demonstration of eNOS and iNOS, tissue samples were fixed in Bouin's solution for $12 \mathrm{~h}$, as described previously (Berisha et al. 2004). The specimens were dehydrated and embedded in paraffin wax. Serial sections $(5 \mu \mathrm{m})$ were cut on a Leitz microtome and collected on gelatin/chrom alum-coated slides. To expose antigenic sites, dewaxed sections were heated four times to $95^{\circ} \mathrm{C}$ in a $600 \mathrm{~W}$ microwave oven in citrate buffer for $5 \mathrm{~min}$. Endogenous peroxidase activity was then eliminated by incubation with $0.5 \%(\mathrm{v} / \mathrm{v}) \mathrm{H}_{2} \mathrm{O}_{2}$ solution in absolute methanol for $15 \mathrm{~min}$ at $20{ }^{\circ} \mathrm{C}$. Non-specific protein binding was eliminated by incubation with $10 \%$ normal goat serum in PBS for $1 \mathrm{~h}$ at $20{ }^{\circ} \mathrm{C}$. Sections were then incubated with either polyclonal rabbit antibody against iNOS (Upstate, Lake Placid, NY, USA) (Sherman et al. 1999), which is known to cross-react with bovine iNOS, or monoclonal rabbit antibody against eNOS (Alpha Diagnostic, San Antonio, TX, USA), from which the human peptide sequence is $100 \%$ conserved in the bovine (Marsden et al. 1992, Welter et al. 2004). Each was used at a dilution of 1:200. Incubation was performed at $18 \mathrm{~h}$ at $4{ }^{\circ} \mathrm{C}$ in a humidified chamber. This was followed by incubating the sections with biotinylated anti-rabbit IgG 1:400 (Amersham-Pharmacia) for $1 \mathrm{~h}$. The sections were then incubated with $\mathrm{ABC}$ reagent from a commercial kit (Vector Laboratories, Burlingame, CA, USA). The bound complex was made visible by reaction with $0.05 \% 3,3-\mathrm{DAB}$ and $0.0006 \% \mathrm{H}_{2} \mathrm{O}_{2}$ in $0 \cdot 1 \times$ PBS. Sections were viewed unstained or counterstained in Mayer's haematoxylin, dehydrated, cleared and mounted. Controls were performed by either replacing primary antibody with buffer or non-immune serum, or incubating with $\mathrm{DAB}$ reagent alone to exclude the possibility of non-suppressed endogenous peroxidase activity. Lack of detectable staining in the controls demonstrated the specificity of the reactions.

\section{Results}

A first screening of eNOS and iNOS mRNA in bovine oviduct total RNA by conventional RT-PCR led to different amplification signal intensities, as shown in Fig. 1. To further characterise these preliminary results, a real-time RT-PCR approach was applied to quantify the gene expression patterns in oviduct epithelial cells.

Transcripts of eNOS and iNOS were detected in BOEC throughout the oestrous cycle. A statistical analysis of eNOS/iNOS transcript concentrations from the ipsiversus contralateral side revealed no significant differences at any time point $(P=0 \cdot 07)$ in either ampulla or isthmus. 


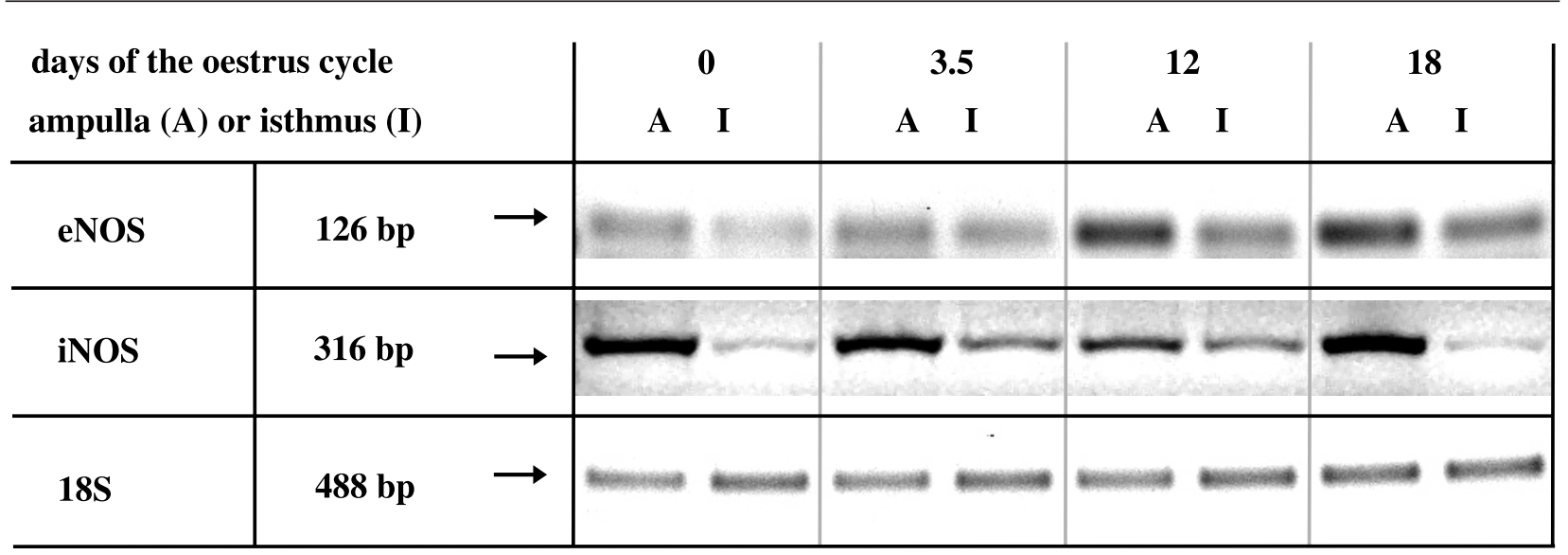

Figure 1 Messenger RNA transcripts of the housekeeping gene 18S and the target genes eNOS and iNOS in the bovine oviduct during the oestrus cycle, exemplified by conventional RT-PCR demonstrating differential expression between ampulla and isthmus as well as between the days of the oestrous cycle. One representative experiment is shown.

Therefore ipsi- and contralateral oviducts were grouped, so that each bar in Fig. 2 represents a data set of six individual oviducts from three different animals.

The eNOS mRNA expression in the ampulla was low at oestrus (day 0 ) and increased significantly, more than threefold, until reaching the highest levels at pro-oestrus (day 18$)(70 \cdot 7$ and $245 \cdot 4 \mathrm{fg} \mathrm{mRNA} / \mu \mathrm{g}$ total RNA respectively) (Fig. 2A). The same tendency was observed in the isthmus, yet here the differences between days 0 and 18 were not significant. Immunoreactive protein was observed in endothelial cells of blood vessels (data not shown). Additionally, supranuclear staining in secretory epithelial cells of the oviduct epithelium was visible at day 18 (Fig. 3A). Nuclear and cytoplasmic staining of both smooth muscle and endothelial cells of small blood vessels could be detected also in the lamina muscularis (Fig. 3B).

The highest transcript amounts for iNOS were detected in the ampulla (3680 $\mathrm{fg} \mathrm{mRNA} / \mu \mathrm{g}$ total RNA at day 18), high levels being retained throughout the oestrous cycle (Fig. 2B). At oestrus (day 0), transcript levels in the isthmus were almost 10-fold lower than in the ampulla (333.8 and $2950 \mathrm{fg} \mathrm{mRNA} / \mu \mathrm{g}$ total RNA respectively). At day 3.5 the iNOS expression in the isthmus was already again as high as in the ampulla (3246 and $2657 \mathrm{fg}$ mRNA/ $\mu \mathrm{g}$ total RNA respectively). It declined to an intermediate level at day 12 , which was significantly lower than at day $3.5(810.7 \mathrm{fg} \mathrm{mRNA} / \mu \mathrm{g}$ total RNA in the isthmus). At pro-oestrus (day 18), there was a significantly lower iNOS mRNA concentration (threefold) in the isthmus than the ampulla (1222 and $3676 \mathrm{fg} \mathrm{mRNA} / \mu \mathrm{g}$ total RNA respectively). In situ hybridisation revealed transcripts in the epithelial cells mainly in the oviductal ampulla at pro-oestrus and oestrus (Fig. $3 \mathrm{G}$ and $\mathrm{H}$ ), in accordance with the high mRNA transcript levels measured by real-time RT-PCR (Fig. 2). Immunohistochemical analysis revealed a conspicious supranuclear staining in secretory epithelial cells mainly toward the lumen (Fig. 3C). The staining appeared mostly at the apical, and not in the basal parts of the luminal branching folds (Fig. 3E). Additionally, pronounced nuclear staining of the lamina muscularis was observed (Fig. 3D and F). The stroma was consistently devoid of iNOS protein (Fig. 3C and E).

The stimulation of BOEC with oestradiol-17 $\beta$ had no effect on the transcript regulation of eNOS (Fig. 4A). However, progesterone significantly stimulated eNOS transcript levels more than threefold only $2 \mathrm{~h}$ after application ( 36.7 and $112 \mathrm{fg} \mathrm{mRNA} / \mu \mathrm{g}$ total RNA respectively) (Fig. 4A).

Nor did oestradiol-17 $\beta$ have an effect on the transcript regulation of iNOS in cultured BOEC (Fig. 4B). But a significant twofold upregulation of iNOS transcript abundance was observed 6 and $12 \mathrm{~h}$ after progesterone stimulation (399 and $904 \mathrm{fg} \mathrm{mRNA} / \mu \mathrm{g}$ total RNA, and 368 and $883 \mathrm{fg} \mathrm{mRNA} / \mu \mathrm{g}$ total RNA respectively) (Fig. 4B).

\section{Discussion}

This study demonstrates the presence of the two isoenzymes eNOS and iNOS in the bovine oviduct during the oestrous cycle. Moreover, immunoreactive protein of eNOS and iNOS could be located in distinct cell types of the oviduct.

In agreement with our mRNA data for iNOS, the lowest expression of NADPH diaphorase as a marker for NOS was found in the isthmus at oestrus (Gawronska et al. 2000). High expression was noticed during the luteal phase (Gawronska et al. 2000). The presence of NADPH diaphorase activity in the porcine oviduct has been demonstrated during the oestrous cycle. Bryant et al. (1995) showed reduced NO activity during late prooestrus by measuring the conversion of $\mathrm{L}$-arginine to L-citrulline in the rat oviduct, and eNOS in the 
(A) eNOS

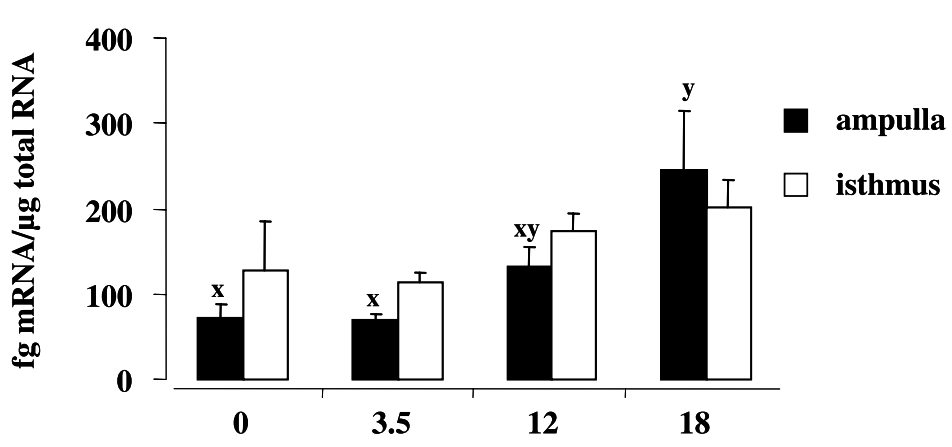

days of the estrous cycle

(B) iNOS

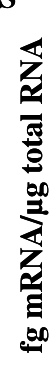

$\left.\begin{array}{r}5000 \\ 4000 \\ 3000 \\ 2000 \\ 1000 \\ 0\end{array}\right]$
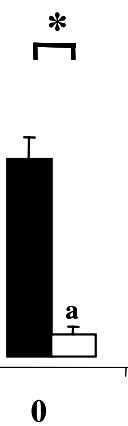

$\mathbf{0}$

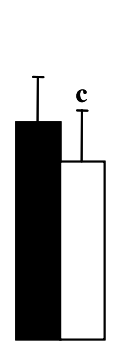

3.5

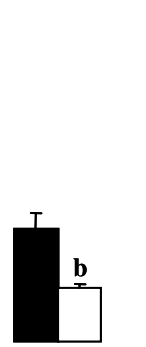

12

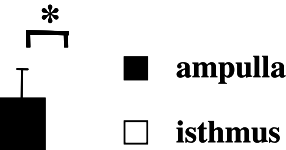

18

days of the estrous cycle

Figure 2 Messenger RNA expression (real-time RT-PCR) of (A) eNOS and (B) iNOS in bovine oviduct cells during the oestrous cycle in either ampulla ( $\mathbf{\square})$ or isthmus ( $\square$ ). eNOS mRNA was significantly upregulated in the ampulla between oestrus (day 0 ) and pro-oestrus (day 18). There was a remarkable downregulation of iNOS mRNA in the isthmus compared with the ampulla at oestrus (day 0) and dioestrus (day 18). Data are presented as means of mRNA/total RNA \pm S.E.M. normalised by $18 \mathrm{~S}(n=6)$. *Significant differences between ampulla and isthmus $(P<0 \cdot 05)$. Different superscript letters indicate significant differences between days of the oestrous cycle $(P<0 \cdot 05)$.

rat oviduct was most prevalent at pro-oestrus and oestrus (Chatterjee et al. 1996). The latter result may point to a direct oestradiol effect on eNOS in rats, but this was not confirmed in the present study for the cow. Instead, the rising levels of eNOS mRNA between oestrus (day 0 ), dioestrus (day 3.5 and 12) and pro-estrus (day 18) indicate the dependency of eNOS on progesterone. This assumption is supported by the stimulation of NOS mRNA expression by progesterone in cultured BOEC as well as the eNOS protein staining in vivo mainly at pro-oestrus.

Current data on the localisation of NOS in the oviduct are controversial. NADPH diaphorase was demontrated mainly in the oviduct epithelium of man, rat and pig (Bryant et al. 1995, Ekerhovd et al. 1999, Gawronska et al. 2000), and eNOS protein was consistently present in oviduct epithelial cells of different species (Bryant et al. 1995, Rosselli et al. 1996, Ekerhovd et al. 1997, Gawronska et al. 2000). In the present study, we clearly demonstrate the presence of both eNOS and iNOS in BOEC. Previously, iNOS protein was observed in the epithelium of the human and the rat oviduct (Bryant et al. 1995, Ekerhovd et al. 1997), but not in the pig (Gawronska et al. 2000). These peculiarities may indicate species differences. In the porcine oviduct, eNOS was found to be the predominant isoform (Gawronska et al. 2000). The present results reveal that the absolute expression of iNOS is much higher than eNOS, in addition to a more pronounced regulation during the oestrous cycle. Since the latter isoform produces lower quantities of NO (Ekerhovd et al. 1999), eNOS in the bovine oviduct might be the isoenzyme responsible for the rather constitutive presence of NO.

NADPH diaphorase as well as eNOS was demonstrated in the myosalpinx of the rat and pig (Bryant et al. 1995), and iNOS was also found in smooth muscle of the human oviduct (Ekerhovd et al. 1997). The relaxing effect of NO 

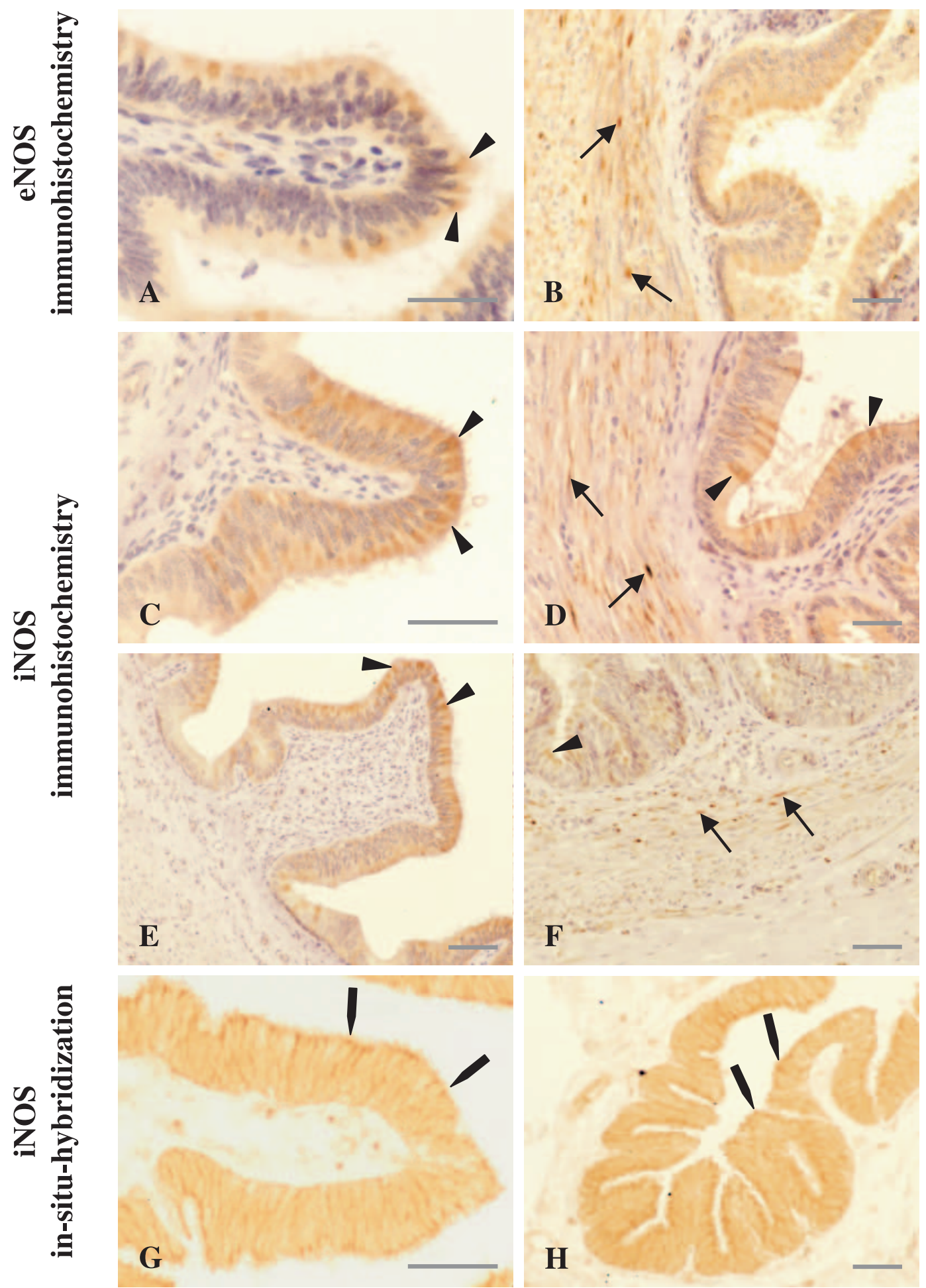

Figure 3 Immunohistochemical localisation of eNOS (A and B) and iNOS (C-F) in bovine oviducts. Black arrowheads (A-F) point at specific immunopositive secretory epithelial cells with supranuclear staining mainly toward the lumen. The staining appeared mostly at the apical, and not in the basal, parts of the luminal branching folds (E). Arrows (A-F) point at immunopositive cells for eNOS and iNOS in the lamina muscularis with pronounced nuclear staining. In situ hybridisation of iNOS (G and H) in bovine oviducts (brown staining) clearly showed positive iNOS mRNA transcripts specifically in epithelial cells of the ampulla (black spearheads). The black bar indicates 50 m. 
(A) eNOS
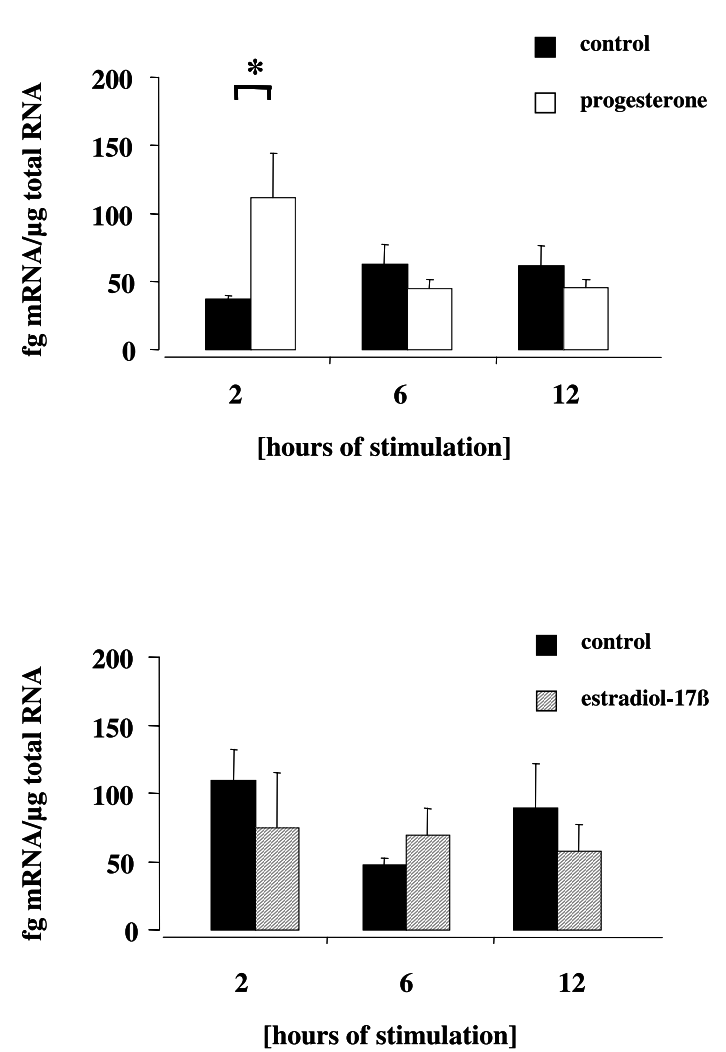

(B) iNOS
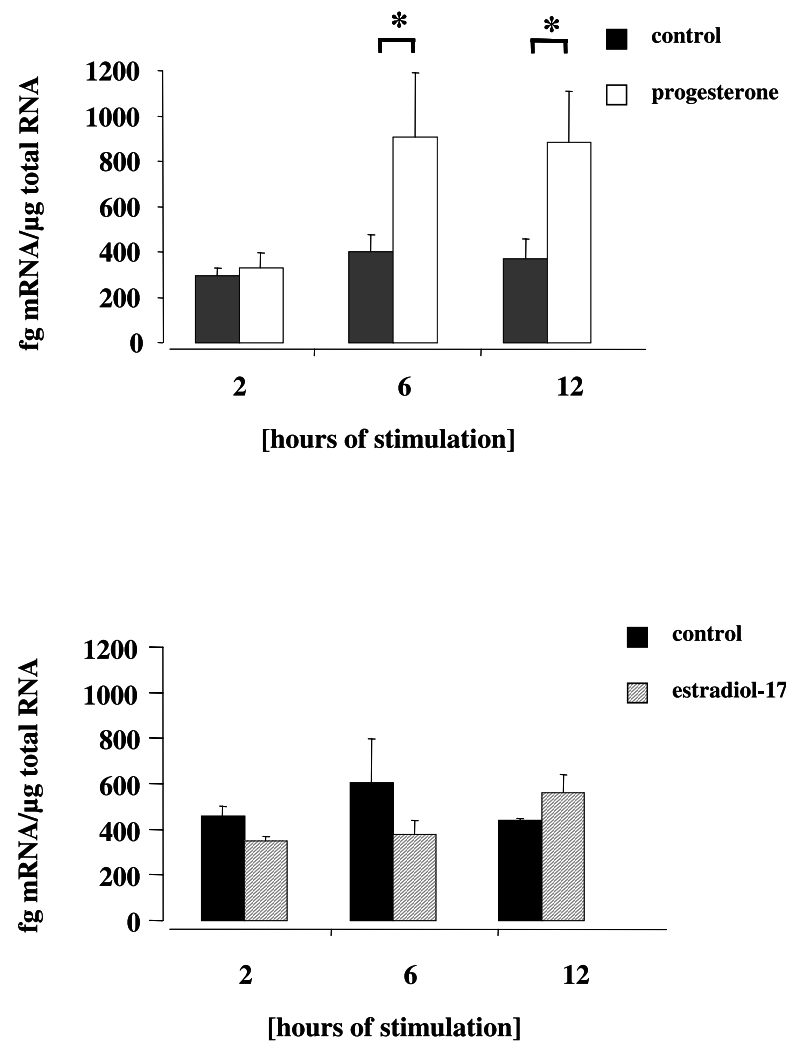

Figure 4 Messenger RNA expression (real-time RT-PCR) of (A) eNOS and (B) iNOS transcripts in a bovine oviduct epithelial cell suspension culture after stimulation with progesterone or oestradiol-17 $\beta$. Transcripts of both eNOS and iNOS were stimulated by progesterone, but not by oestradiol- $17 \beta$. Data are presented as means of mRNA/total RNA \pm S.E.M. normalised by $18 \mathrm{~S}(n=4)$. ${ }^{*}$ Significant differences between control and stimulation $(P<0 \cdot 05)$.

on smooth muscle, possibly controlled by progesterone (Chwalisz 1994), is well known, particularly for uterine quiescence during pregnancy (Yallampalli et al. 1993). The motility patterns of the oviduct show rising frequency and amplitude of motility around oestrus (Bennett et al. 1988). Therefore, several mediators of contraction could be involved in this regulation, influencing or orchestrating the NOS expression in the oviduct, namely, oestradiol, oxytocin, prostaglandin $(\mathrm{PG}) \mathrm{F}_{2 \alpha}, \mathrm{PGE}_{2}$ and endothelin-1 (Moore \& Croxatto 1988, Gilbert et al. 1992, Salvemini et al. 1993, Rosselli et al. 1994, Perez et al. 1998). PGF $2 \alpha$ can induce NO production by NOS in rat oviduct cells (Perez et al. 1998). The highest concentrations of $\mathrm{PGF}_{2 \alpha}$ receptors are found around oestrus in the rat (Orlicky \& Williams-Skipp 1993), and oestradiol is known to activate PG synthase. NO could therefore negatively modulate or antagonise the contractile response of $\mathrm{PGF}_{2 \alpha}$. Furthermore, $\mathrm{NO}$ participates in the release of $\mathrm{PGE}_{2}$ (Salvemini et al. 1993). $\mathrm{PGE}_{2}$ is increased at oestrus (Wijayagunawardane et al. 1998) and has been held to cause relaxation of the oviduct in the presence of progesterone (Gawronska et al. 2000). Subsequently, $\mathrm{PGE}_{2}$, together with progesterone, could regulate NOS expression (Milano et al. 1995), an effect that would agree with the in vitro findings of the present study. Beside these findings, endothelin-1 (ET-1) is high in the ipsilateral oviduct during the follicular and postovulation stage (Wijayagunawardane et al. 1998). ET-1 has been shown to stimulate $\mathrm{NO}$ in $\mathrm{BOEC}$ via endothelin receptor beta (Rosselli et al. 1994). NO reduces the contractile effects of ET-1, hence the interplay of ET-1 and NO might contribute to the physiological relaxation of the oviduct.

Using L-NAME (N-nitro-L-arginine methyl ester), a well-known inhibitor of NOS, Perez et al. (2000) found evidence of increased tubal motility that resulted in accelerated ovum transport into the uterus. Moreover, oestradiol treatment caused increasing contraction frequency of the smooth muscle of the isthmus (Moore \& Croxatto 1988). This could be mediated by oestrogen 
receptor $\beta$, which is more abundant in the isthmus (Ulbrich et al. 2003). The endogenous local downregulation of iNOS in the isthmus could support similar effects. Therefore, our hypothesis is that the downregulation of iNOS at oestrus in the isthmus leads to an increase of oviduct motility by circular smooth muscle activity.

There is evidence that the accelerated movement of microspheres through the isthmus is due to peristaltic smooth muscle contractions, and to ciliary activity, and this is supported by the observation of a reduced number of ciliated cells in the isthmus (Perez et al. 1998). Moreover, the ciliated epithelial cells were mostly devoid of iNOS protein, whereas the lamina muscularis was clearly stained.

In secretory epithelial cells of the oviduct, the nucleus is shifted toward the apical side of the epithelium (unpublished data). We may deduce from this that both eNOS and iNOS proteins target mostly secretory epithelial cells, as has also been shown for eNOS in the human Fallopian tube (Ekerhovd et al. 1999). iNOS protein was found in secretory cells toward the oviduct lumen in the supranuclear region; therefore, it can be assumed that NO is released into the lumen. It might be of further interest to know whether the produced $\mathrm{NO}$ is also secreted toward the stroma and myosalpinx, or whether eNOS found in smooth muscle cells affects the contractibility of the oviduct. The contribution of NOS might be important for relaxation together with a local exertion during (pro-)oestrus, facilitating capture, retention and fertilisation of the released oocyte and the active transport of the conceptus (Chatterjee et al. 1996). Furthermore, through the ability of iNOS to produce cytotoxic levels of NO (Guo et al. 1995), the downregulation of iNOS in the isthmus at oestrus could be an implicit protective mechanism for advancing sperm and the developing embryo.

The present study does not take into account further regulation of NOS enzyme activity. In particular, the proposed differences in enzyme activity of both NOS isoforms (Presta et al. 1997) cannot be measured through expression analysis solely. Nonetheless, this investigation provides new data on a local NO-regulating mechanism in the bovine oviduct.

In summary, the present results provide evidence of the presence of NOS in the bovine oviduct. The regionspecific modulated mRNA expression patterns of eNOS and iNOS during the oestrous cycle indicate a local regulatory system of $\mathrm{NO}$ in the bovine oviduct and suggest a different role of $\mathrm{NO}$ in the ampulla and the isthmus region. Although functional analyses still remain to be done, the conspicious downregulation of iNOS at oestrus in the isthmus requires further research. NO might represent another important local factor regulating oviducal functions with possible impact on contractility response. The present findings underline the physiological influence of both NOS in supporting a successful fertilisation by regulating the oviduct environment.

\section{Acknowledgements}

This study was supported by Deutsche Forschungsgemeinschaft (DFG Ei 296/10-2) and Evangelisches Studienwerk e.V. The authors declare that there is no conflict of interest that would prejudice the impartiality of this scientific work.

\section{References}

Bauersachs S, Ulbrich SE, Meyer HHD, Einspanier R, Gross K, Schmidt S, Wenigerkind H, Vermehren M, Blum H, Sinowatz F et al. 2005 Gene expression profiling of bovine endometrium during the estrous cycle-detection of molecular pathways involved in functional changes. Journal of Molecular Endocrinology 34 889-908.

Bennett WA, Watts TL, Blair WD, Waldhalm SJ \& Fuquay JW 1988 Patterns of oviducal motility in the cow during the oestrous cycle. Journal of Reprododuction and Fertility 83 537-543.

Berisha B, Pfaffl MW \& Schams D 2002 Expression of estrogen and progesterone receptors in the bovine ovary during estrous cycle and pregnancy. Endocrine 17 207-214.

Berisha B, Sinowatz F \& Schams D 2004 Expression and localisation of fibroblast growth factor (FGF) family members during the final growth of bovine ovarian follicles. Molecular Reproduction and Development 67 162-171.

Bryant CE, Tomlinson A, Mitchell JA, Thiemermann C \& Willoughby DA 1995 Nitric oxide synthase in the rat fallopian tube is regulated during the oestrous cycle. Journal of Endocrinology 146 149-157.

Chatterjee S, Gangula PR, Dong YL \& Yallampalli C 1996 Immunocytochemical localisation of nitric oxide synthase-III in reproductive organs of female rats during the oestrous cycle. Histochemical Journal 28 715-723.

Chwalisz K 1994 The use of progesterone antagonists for cervical ripening and as an adjunct to labour and delivery. Human Reproduction 9 (Suppl 1) 131-161.

Einspanier R, Schonfelder M, Muller K, Stojkovic M, Kosmann M, Wolf E \& Schams D 2002 Expression of the vascular endothelial growth factor and its receptors and effects of VEGF during in vitro maturation of bovine cumulus-oocyte complexes (COC). Molecular Reproduction and Development 62 29-36.

Ekerhovd E, Brannstrom M, Alexandersson M \& Norstrom A 1997 Evidence for nitric oxide mediation of contractile activity in isolated strips of the human Fallopian tube. Human Reproduction 12 301-305.

Ekerhovd E, Brannstrom M, Weijdegard B \& Norstrom A 1999 Localisation of nitric oxide synthase and effects of nitric oxide donors on the human Fallopian tube. Molecular Human Reproduction 5 1040-1047.

Furchgott RF \& Vanhoutte PM 1989 Endothelium-derived relaxing and contracting factors. FASEB Journal 3 2007-2018.

Gawronska B, Bodek G \& Ziecik AJ 2000 Distribution of NADPH-diaphorase and nitric oxide synthase (NOS) in different regions of porcine oviduct during the estrous cycle. Journal of Histochemistry and Cytochemistry 48 867-875.

Gilbert CL, Cripps PJ \& Wathes DC 1992 Effect of oxytocin on the pattern of electromyographic activity in the oviduct and uterus of the ewe around oestrus. Reproduction, Fertility, and Development 4 193-203.

Guo FH, De Raeve HR, Rice TW, Stuehr DJ, Thunnissen FB \& Erzurum SC 1995 Continuous nitric oxide synthesis by inducible nitric oxide synthase in normal human airway epithelium in vivo. PNAS 92 7809-7813.

Guzik TJ, Korbut R \& Adamek-Guzik T 2003 Nitric oxide and superoxide in inflammation and immune regulation. Journal of Physiological Pharmacology 54 469-487. 
Ignarro LJ, Buga GM, Wei LH, Bauer PM, Wu G \& del Soldato P 2001 Role of the arginine-nitric oxide pathway in the regulation of vascular smooth muscle cell proliferation. PNAS 98 4202-4208.

Jablonka-Shariff A, Basuray R \& Olson LM 1999 Inhibitors of nitric oxide synthase influence oocyte maturation in rats. Journal of the Society for Gynecologic Investigation 6 95-101.

Marsden PA, Schappert KT, Chen HS, Flowers M, Sundell CL, Wilcox JN, Lamas S \& Michel T 1992 Molecular cloning and characterisation of human endothelial nitric oxide synthase. FEBS Letters 307 287-293.

Maul H, Longo M, Saade GR \& Garfield RE 2003 Nitric oxide and its role during pregnancy: from ovulation to delivery. Current Pharmaceutical Design 9 359-380.

Milano S, Arcoleo F, Dieli M, D'Agostino R, D'Agostino P, De Nucci G \& Cillari E 1995 Prostaglandin $E_{2}$ regulates inducible nitric oxide synthase in the murine macrophage cell line J774. Prostaglandins 49 105-115.

Moncada S, Higgs A \& Furchgott R 1997 International Union of Pharmacology nomenclature in nitric oxide research. Pharmacological Reviews 49 137-142.

Moore GD \& Croxatto HB 1988 Effects of delayed transfer and treatment with oestrogen on the transport of microspheres by the rat oviduct. Journal of Reproduction and Fertility 83 795-802.

Nathan C \& Xie QW 1994 Nitric oxide synthases: roles, tolls, and controls. Cell 78 915-918.

Orlicky DJ \& Williams-Skipp C 1993 Immunohistochemical localisation of PGF2 alpha receptor in the rat oviduct. Prostaglandins, Leukotrienes, and Essential Fatty Acids 48 185-192.

Perez MS, Franchi AM, Viggiano JM, Herrero MB \& Gimeno M 1998 Effect of prostaglandin F2 alpha (PGF2 alpha) on oviductal nitric oxide synthase (NOS) activity: possible role of endogenous NO on PGF2 alpha-induced contractions in rat oviduct. Prostaglandins and Other Lipid Mediators 56 155-166.

Perez MS, Viggiano M, Franchi AM, Herrero MB, Ortiz ME, Gimeno MF \& Villalon M 2000 Effect of nitric oxide synthase inhibitors on ovum transport and oviductal smooth muscle activity in the rat oviduct. Journal of Reproduction and Fertility 118 111-117.

Presta A, Liu J, Sessa WC \& Stuehr DJ 1997 Substrate binding and calmodulin binding to endothelial nitric oxide synthase coregulate its enzymatic activity. Nitric Oxide 1 74-87.

Rosselli M, Dubey RK, Rosselli MA, Macas E, Fink D, Lauper U, Keller PJ \& Imthurn B 1996 Identification of nitric oxide synthase in human and bovine oviduct. Molecular Human Reproduction 2 607-612.

Rottmayer R, Ulbrich SE, Kölle S, Prelle K, Meyer HH, Sinowatz F, Wolf E \& Hiendleder S 2005 A novel suspension culture system for bovine oviduct epithelial cells. Reproduction, Fertility, and Development 1722.

Salvemini D, Misko TP, Masferrer JL, Seibert K, Currie MG \& Needleman P 1993 Nitric oxide activates cyclooxygenase enzymes. PNAS 90 7240-7244.

Sengoku K, Takuma N, Horikawa M, Tsuchiya K, Komori H, Sharifa D, Tamate K \& Ishikawa M 2001 Requirement of nitric oxide for murine oocyte maturation, embryo development, and trophoblast outgrowth in vitro. Molecular Reproduction and Development 58 262-268.

Sherman TS, Chen Z, Yuhanna IS, Lau KS, Margraf LR \& Shaul PW 1999 Nitric oxide synthase isoform expression in the developing lung epithelium. American Journal of Physiology 276 L383-L390.

Shukovski L \& Tsafriri A 1994 The involvement of nitric oxide in the ovulatory process in the rat. Endocrinology 135 2287-2290.

Ulbrich SE, Kettler A \& Einspanier R 2003 Expression and localisation of estrogen receptor alpha, estrogen receptor beta and progesterone receptor in the bovine oviduct in vivo and in vitro. Journal of Steroid Biochemistry and Molecular Biology 84 279-289.

Ulbrich SE, Schoenfelder M, Thoene S \& Einspanier R 2004 Hyaluronan in the bovine oviduct - modulation of synthases and receptors during the estrous cycle. Molecular and Cellular Endocrinology 214 9-18.

Welter H, Bollwein H, Weber F, Rohr S \& Einspanier R 2004 Expression of endothelial and inducible nitric oxide synthases is modulated in the endometrium of cyclic and early pregnant mares. Reproduction, Fertility, and Development 16 689-698.

Wijayagunawardane MP, Miyamoto A, Cerbito WA, Acosta TJ, Takagi M \& Sato K 1998 Local distributions of oviductal estradiol, progesterone, prostaglandins, oxytocin and endothelin- 1 in the cyclic cow. Theriogenology 49 607-618.

Yallampalli C, Garfield RE \& Byam-Smith M 1993 Nitric oxide inhibits uterine contractility during pregnancy but not during delivery. Endocrinology 133 1899-1902.

Received in final form 20 October 2005

Accepted 26 October 2005

Made available online as an Accepted Preprint 18 November 2005 